\title{
Selective expression of muscarinic acetylcholine receptor subtype M3 by mouse type III taste bud cells
}

\author{
Yusuke Mori $^{1} \cdot$ Kohgaku Eguchi $^{1} \cdot$ Kiyonori Yoshii $^{1} \cdot$ Yoshitaka Ohtubo $^{1}$
}

Received: 6 September 2016 / Accepted: 6 September 2016/Published online: 14 September 2016

(C) The Author(s) 2016. This article is published with open access at Springerlink.com

\begin{abstract}
Each taste bud cell (TBC) type responds to a different taste. Previously, we showed that an unidentified cell type(s) functionally expresses a muscarinic acetylcholine (ACh) receptor subtype, M3, and we suggested the ACh-dependent modification of its taste responsiveness. In this study, we found that M3 is expressed by type III TBCs, which is the only cell type that possesses synaptic contacts with taste nerve fibers in taste buds. The application of ACh to the basolateral membrane of mouse fungiform TBCs in situ increased the intracellular $\mathrm{Ca}^{2+}$ concentration in $2.4 \pm 1.4$ cells per taste bud (mean $\pm \mathrm{SD}$, $n=14)$. After $\mathrm{Ca}^{2+}$ imaging, we supravitally labeled type II cells (phospholipase C $\beta 2$ [PLC $\beta 2$ ]-immunoreactive cells) with Lucifer yellow $\mathrm{CH}$ (LY), a fluorescent dye and investigated the positional relationship between ACh-responding cells and LY-labeled cells. After fixation, the TBCs were immunohistostained to investigate the positional relationships between immunohistochemically classified cells and LYlabeled cells. The overlay of the two positional relationships obtained by superimposing the LY-labeled cells showed that all of the ACh-responding cells were type III cells (synaptosomal-associated protein 25 [SNAP-25]-immunoreactive cells). The $\mathrm{ACh}$ responses required no added $\mathrm{Ca}^{2+}$ in the bathing solution. The addition of $1 \mu \mathrm{M}$ U73122, a phospholipase $\mathrm{C}$ inhibitor, decreased the magnitude of the ACh response, whereas that of $1 \mu \mathrm{M} \mathrm{U73343}$, a negative control, had no effect. These results suggest that type III cells respond to $\mathrm{ACh}$ and release $\mathrm{Ca}^{2+}$ from intracellular stores. We also discuss the underlying mechanism of the $\mathrm{Ca}^{2+}$ response and the role of M3 in type III cells.
\end{abstract}

Yoshitaka Ohtubo

otsubo@brain.kyutech.ac.jp

1 Graduate School of Life Science and Systems Engineering, Kyushu Institute of Technology, Kitakyushu 808-0196, Japan
Keywords $\mathrm{Ca}^{2+}$ imaging $\cdot$ Fungiform taste bud $\cdot \mathrm{M} 3$ muscarinic acetylcholine receptor $\cdot$ Peeled lingual epithelia . Immunohistostaining

\section{Introduction}

The responsiveness of taste bud cells (TBCs) depends on their cell types. Type II cells detect sweet, bitter, and umami substances [2, 3, 21, 23, 25, 26], and type III cells are considered to sense acidic substances $[14,17,36]$ as well as mediate the taste responses of type II cells to the brain $[4,10,13]$.

TBCs express neurotransmitter receptors for acetylcholine (ACh), ATP, serotonin, adrenaline, and cholecystokinin [5, 8, $10-12,16,18,19,27]$. In our previous study, we showed that unidentified TBCs expressed a muscarinic ACh receptor subtype, M3, and these TBCs exhibited increased intracellular $\mathrm{Ca}^{2+}$ concentrations in response to $\mathrm{ACh}$ [8]. If the expression of M3 depends on the cell type, then the ACh released in taste bud selectively modifies the response according to the cell type. Therefore, we focused on the identification of cell type which functionally expresses M3.

In the present study, we identified the cell type that functionally expresses M3 in situ. As the antibodies against mouse M3 for immunohistochemical uses were unavailable to us, we employed Lucifer yellow CH (LY)-labeled type II cells under supravital staining conditions [32]. Thus, we labeled type II cells with $\mathrm{LY}$ after identifying ACh-responding cells by $\mathrm{Ca}^{2+}$ imaging and investigated the positional relationships between the LY-labeled cells and the ACh-responding cells. Next, we fixed TBCs and immunohistochemically classified the cells according to three types - type II cells, type III cells, and non-immunoreactive cells - before investigating the positional relationships between LY-labeled cells and each cell type in the taste bud. The overlay of the two positional relationships 
obtained by superimposing the LY-labeled cells identified the cell type of the ACh-responding cells. Thus, we show that M3 is selectively expressed by type III cells. We discuss the underlying mechanism that allows $\mathrm{M} 3$ to elicit $\mathrm{Ca}^{2+}$ responses and the role of $\mathrm{M} 3$ in taste responses.

\section{Preparation of peeled lingual epithelia}

We killed ca. 6-week-old ddY strain mice of either sex by exposure to $\mathrm{CO}_{2}$ followed by decapitation. We removed their tongues and hypodermically injected an elastase solution into the tongue, before peeling the lingual epithelia containing fungiform taste buds. The peeled epithelium was mounted on a recording platform with the basolateral membrane side facing upward and then placed under a $60 \times$ water immersion objective (Fluor-60×, Olympus, Tokyo, Japan), as described previously $[8,10,20]$. The basolateral membrane side of the peeled epithelium was irrigated with either a control bathing solution or a test solution by exchanging the composition of the water column between the water immersion objective and the basolateral membrane side. The receptor membrane side facing inside the platform was allowed to acclimate to the control bathing solution.

\section{$\mathrm{Ca}^{2+}$ imaging}

We also examined the $\left[\mathrm{Ca}^{2+}\right]_{\text {in }}$ of TBCs in response to $\mathrm{ACh}$, as described previously $[8,10]$, except we used another charge-coupled device (CCD) camera (C910013, Hamamatsu Photonics, Hamamatsu, Japan) to lower the noise and increase the resolution from 12-bit to 16bit to clarify the outline of the ACh-sensitive TBCs. In brief, we soaked the basolateral membrane side of the peeled epithelium mounted on the recording platform in Fura-2 AM solution, which was then placed under a fluorescent microscope equipped with the water immersion objective lens. The Fura-2-stained TBCs were excited at $340 \mathrm{~nm}$ (F340) and $380 \mathrm{~nm}$ (F380) with a spectroscope-type high-speed wavelength changer (C7773, Hamamatsu Photonics). Images of Fura-2 fluorescence were acquired every $2.5 \mathrm{~s}$ using the CCD camera through the water immersion objective, stored in a computer, and analyzed with AQUACOSMOS software (version 2.6, Hamamatsu Photonics). We sequentially plotted the averaged $\left[\mathrm{Ca}^{2+}\right]_{\text {in }}$ over the respective cell areas as the ratio of F340/F380, and we took the peak magnitude of the ratio as the response magnitude. The response magnitude was normalized against that elicited by $1 \mu \mathrm{M}$ ACh dissolved in the control bathing solution, and we expressed the normalized response magnitude as the mean \pm SD unless stated otherwise.
We also plotted the number of ACh-responding cells as the mean $\pm \mathrm{SD}$.

\section{LY labeling without fixation}

After the $\mathrm{Ca}^{2+}$ imaging study, we supravitally labeled type II cells in the taste buds with LY, as described previously [32]. In brief, we acclimated the basolateral membrane of TBCs in the peeled lingual epithelium to the control bathing solution under the microscope, before applying $200 \mathrm{mM} \mathrm{K}^{+}$bathing solution containing $0.4 \mathrm{mg} / \mathrm{ml} \mathrm{LY}$ to the basolateral membrane for $2 \mathrm{~min}$ in the dark, washing with the control bathing solution, and capturing a fluorescence image of the LY-labeled cells with the CCD camera. Care was taken to prevent the taste bud from moving, which was essential for investigating the positional relationships between ACh-responding cells and LY-labeled cells.

\section{Immunohistochemistry}

After $\mathrm{Ca}^{2+}$ imaging and LY labeling, we fixed and immunohistostained the TBCs to investigate the positional relationships between the LY-labeled cells and each immunohistochemical cell type. It should be noted that the fluorescence of LY was still very clear after immunohistostaining.

The method employed for immunostaining and obtaining fluorescent images was similar to that used in our previous studies $[8,10,29,30]$. In brief, the peeled lingual epithelium was fixed with paraformaldehyde solution at $4{ }^{\circ} \mathrm{C}$, incubated in blocking solution containing $3 \%$ normal goat serum, $0.3 \%$ Triton $\mathrm{X}$, and $1 \%$ bovine serum albumin in phosphate-buffered saline (PBS), incubated with primary antibodies dissolved in the blocking solution at $4{ }^{\circ} \mathrm{C}$ for $24-48 \mathrm{~h}$, rinsed with PBS, and incubated with Alexa Fluor-conjugated secondary antibodies dissolved in the blocking solution at $4{ }^{\circ} \mathrm{C}$ for $24-48 \mathrm{~h}$. The epithelium was mounted on glass slides and then sliced optically and horizontally to obtain fluorescence images of the immunostained and LY-labeled TBCs with a laser scanning confocal microscope system (Leica Microsystems, Bensheim, Germany). It should be noted that the fluorescence due to immunoreactivity and LY was captured in the same focal plane.

The primary antibodies were anti-SNAP-25 mouse monoclonal antibody (1:1000; Sigma, St. Louis, MO, USA) and anti-PLC $\beta 2$ rabbit antibody (1:100; Santa Cruz Biotechnology). The secondary antibodies were Alexa Fluor 488-conjugated goat anti-rabbit IgG (1:400; Molecular Probes, Eugene, OR, USA) and Alexa Fluor 555-conjugated goat anti-mouse $\operatorname{IgG}$ (1:400; Molecular Probes). 


\section{Multiplex nested reverse transcription polymerase chain reaction}

We searched for messenger RNAs (mRNAs) encoding enzymes involved in $\mathrm{IP}_{3}$ cascades using mouse fungiform taste buds isolated from peeled lingual epithelia, as described previously $[8,10]$. In brief, we soaked the peeled lingual epithelium in a nominally $\mathrm{Ca}^{2+}$ - and $\mathrm{Mg}^{2+}$-free solution for ca $1 \mathrm{~min}$, puffed the nominally $\mathrm{Ca}^{2+}$ - and $\mathrm{Mg}^{2+}$-free solution through a pipette onto the cleft between a taste bud and the surrounding epithelium cells in the control bathing solution under the microscope, and then collected the liberated taste bud with another suction pipette. The taste buds were collected and used in the PCR experiments describe as follows:

We employed multiplex nested reverse transcription polymerase chain reaction (RT-PCR), which comprises two steps (first RT-PCR and second PCR), thereby reducing the number of mice sacrificed. The first RT-PCR was performed using a OneStep RT-PCR Kit (Qiagen, Valencia, CA). Three taste buds were added to a RTPCR mix containing RNase inhibitor (Takara Bio Inc., Siga, Japan) and $0.6 \mu \mathrm{M}$ outer primers (Table 1). The RT-PCR conditions were as follows: reverse transcription, $50{ }^{\circ} \mathrm{C}$ for $30 \mathrm{~min}$; initial PCR activation step, $95{ }^{\circ} \mathrm{C}$ for $15 \mathrm{~min}$; denaturation, 40 cycles at $94^{\circ} \mathrm{C}$ for $30 \mathrm{~s}$; annealing, $58{ }^{\circ} \mathrm{C}$ for $1 \mathrm{~min}$; extension, $72{ }^{\circ} \mathrm{C}$ for $1.5 \mathrm{~min}$; and final extension, $72{ }^{\circ} \mathrm{C}$ for $10 \mathrm{~min}$. The amplified products $(2 \mu \mathrm{l})$ were added to the second PCR mix containing DNA polymerase KOD plus (Toyobo Co. Ltd., Osaka, Japan) and $0.6 \mu \mathrm{M}$ inner primers (Table 1). The conditions for the second round of PCR were as follows: predenaturation, $94{ }^{\circ} \mathrm{C}$ for $2 \mathrm{~min}$; denaturation, 40 cycles at
$94{ }^{\circ} \mathrm{C}$ for $30 \mathrm{~s}$; annealing, $58{ }^{\circ} \mathrm{C}$ for $30 \mathrm{~s}$; extension, $68{ }^{\circ} \mathrm{C}$ for $1 \mathrm{~min}$; and final extension, $68^{\circ} \mathrm{C}$ for $10 \mathrm{~min}$. The PCR products were analyzed by $2 \%$ agarose gel electrophoresis, stained with ethidium bromide $(0.1$ $\mu \mathrm{g} / \mathrm{ml}$ ), and visualized by ultraviolet illumination.

The optimum annealing temperatures were determined in preliminary PCR experiments using brain tissue and peeled lingual epithelium containing TBCs. We tested a range of annealing temperatures from 50 to $62{ }^{\circ} \mathrm{C}$ in $4{ }^{\circ} \mathrm{C}$ steps, and we selected the annealing temperature that yielded a clear single band with the correct size on agarose gels for each primer set. As cell type markers, we used nucleoside triphosphate diphosphohydrolase 2 (NTPD2) for type I cells; phospholipase C $\beta 2$ (PLC $\beta 2$ ) and type III inositol 1,4,5-triphosphate receptor $\left(\mathrm{IP}_{3} \mathrm{R} 3\right)$ for type II cells; and synaptosomalassociated protein 25 (SNAP-25) for type III cells. The primers were obtained from Genenet (Fukuoka, Japan).

\section{Solutions}

Unless stated otherwise, all of the reagents were obtained from Wako (Osaka, Japan). All of the solutions were prepared with deionized water and the components were expressed in millimolar concentrations, unless stated otherwise.

The control bathing solution comprised $150 \mathrm{NaCl}, 5 \mathrm{KCl}, 2$ $\mathrm{CaCl}_{2}, 0.5 \mathrm{MgCl}_{2}, 10$ glucose, and 5 HEPES (Sigma, St. Louis, MO), which was buffered to $\mathrm{pH} 7.4$ with $\mathrm{NaOH}$. The $200 \mathrm{mM} \mathrm{K}^{+}$bathing solution was prepared by increasing the $\mathrm{KCl}$ concentration to $200 \mathrm{mM}$ and eliminating $\mathrm{NaCl}$ from the control bathing solution. The $50 \mathrm{mM} \mathrm{K}^{+}$bathing solution was prepared by replacing isomolar $\mathrm{Na}^{+}$in the control bathing solution. The nominally $\mathrm{Ca}^{2+}$-free bathing solution was prepared by replacing $\mathrm{CaCl}_{2}$ with $\mathrm{MgCl}_{2}$ in the control bathing

Table 1 Sequences of primer sets used for multiplex nested RT-PCR

\begin{tabular}{|c|c|c|c|c|}
\hline Protein & & Forward primer $5^{\prime}-3^{\prime}$ & Reverse primer $5^{\prime}-3^{\prime}$ & $\begin{array}{l}\text { Product } \\
\text { size (bp) }\end{array}$ \\
\hline \multirow[t]{2}{*}{$\operatorname{PLC} \beta 2$} & Outer & AGCCTAAGCTTCCTCTCCTG & AGGAGTTGAGTCGAGGGTCT & 865 \\
\hline & Inner & CTCGCTTTGGGAAGTTTGC & GCATTGACTGTCATCGGGT & 226 \\
\hline \multirow[t]{2}{*}{ PLC $\beta 3$} & Outer & TCAAGGTCTGGTCAGAGGAG & GATGGCCTCTAGCACATCAC & 806 \\
\hline & Inner & GGAGCAGCTCATGGACTTTA & CATACATCCAGCTCCACACA & 369 \\
\hline \multirow[t]{2}{*}{$\mathrm{IP}_{3} \mathrm{R} 3$} & Outer & GTCTGTAACAAGCGGGAGAA & GACTTGCGGTTCTGGAGATA & 749 \\
\hline & Inner & CCAACCAGTGGGACTACAAG & CGAACTTGCTCTTCTTCAGC & 291 \\
\hline \multirow[t]{2}{*}{$\mathrm{IP}_{3} \mathrm{R} 1$} & Outer & CCTGTCTTTGTGCAACTCCT & CTCCTTGTCGAGGTGACACT & 888 \\
\hline & Inner & CATAGCCATTCCTGTTGACC & CTCCAGCAGTTGCTTGGTAT & 352 \\
\hline \multirow[t]{2}{*}{ SNAP-25 } & Outer & AGGAAGGGATGGACCAAATC & GGGGGTGACTGACTCTGTGT & 600 \\
\hline & Inner & GGCAATAATCAGGATGGAGTAG & AAATTTAACCACTTCCCAGCA & 310 \\
\hline \multirow[t]{2}{*}{ NTPD2 } & Outer & CCTCAAGTATGGCATCGTTC & TATTGAAGAGCCCAGAGACG & 848 \\
\hline & Inner & GTGACTGCCAACTACCTGCT & GACCCATAGTGCATGGAGAC & 352 \\
\hline
\end{tabular}

Each outer primer set was mixed in a single tube containing the collected taste buds and reagents for one-step RT-PCR. The amplicon and inner primer sets were used for second PCR in individual reaction tubes 
solution. Earle's solution comprised $116 \mathrm{NaCl}, 5.4 \mathrm{KCl}, 1.8$ $\mathrm{CaCl}_{2}, 0.8 \mathrm{MgSO}_{4}, 26.2 \mathrm{NaHCO}_{3}$, and $1 \mathrm{NaH}_{2} \mathrm{PO}_{4}$. PBS comprised $137 \mathrm{NaCl}, 2.7 \mathrm{KCl}, 8.1 \mathrm{Na}_{2} \mathrm{HPO}_{4}$, and 1.5 $\mathrm{KH}_{2} \mathrm{PO}_{4}$. The elastase solution was prepared by dissolving $0.1 \%$ elastase in the control bathing solution. The Fura-2 AM solution comprised 12.5 $\mu \mathrm{M}$ Fura-2 AM (Molecular Probes, Eugene, OR) dissolved in Earle's solution supplemented with $0.25 \%$ Pluronic F-127 (Sigma). The paraformaldehyde solution was $4 \%$ paraformaldehyde dissolved in PBS. The LY solution comprised $0.4 \mathrm{mg} / \mathrm{ml} \mathrm{LY} \mathrm{(Sigma)} \mathrm{dissolved}$ in the $200 \mathrm{mM} \mathrm{K}^{+}$bathing solution. The nominally $\mathrm{Ca}^{2+}$ - and $\mathrm{Mg}^{2+}$-free solution comprised $150 \mathrm{NaCl}, 5 \mathrm{KCl}, 10$ glucose, and 5 HEPES, which were buffered to $\mathrm{pH} 7.4$ with $\mathrm{NaOH}$.

\section{Results}

\section{Cell type for the ACh-responding cells}

The application of $1 \mu \mathrm{M}$ ACh dissolved in the control bathing solution to the basolateral membrane side transiently increased $\left[\mathrm{Ca}^{2+}\right]_{\text {in }}$ in a few TBCs per taste bud, i.e., $2.4 \pm 1.4$ cells (mean $\pm \mathrm{SD}, n=14$; Fig. $1 \mathrm{a}-\mathrm{c}$ ). Immediately after the $\mathrm{Ca}^{2+}$ imaging experiments were complete, we supravitally labeled type II cells in a taste bud with LY without moving the taste bud and investigated the positional relationships between the AChresponding cells and the LY-labeled cells (Fig. 2a-c). We fixed the taste bud and immunohistochemically identified the cell type of the same TBC (Fig. 2d-f). The fluorescence of LY-labeled cells was still distinguishable after immunohistostaining. The overlay of the two positional relationships obtained by superimposing the LY- labeled cells in two positional relationships clearly showed that all of the ACh-responding cells were SNAP-25-immunoreactive (Fig. 2g).

Using this method, we investigated the cell types for 34 ACh-responding cells in 14 taste buds. All of the AChresponding cells examined were immunoreactive to SNAP25 . PLC $\beta 2$-immunoreactive cells or non-immunoreactive cells did not respond to ACh. Not all of the SNAP-25immunoreactive cells were ACh-responding cells, i.e., among 44 SNAP-25-immunoreactive cells found in these 14 taste buds, $10(\sim 23 \%)$ did not respond to ACh. These results showed that the ACh-responding cells comprised a subtype of the SNAP-25-immunoreactive cells.

\section{$\mathrm{Ca}^{2+}$ responses of $\mathrm{ACh}-$ responding cells to $\mathrm{KCl}$-induced depolarization}

Our results showed that the ACh-responding cells were immunoreactive to SNAP-25. SNAP-25-immunoreactive cells are identical to type III cells, and type III cells cause $\mathrm{Ca}^{2+}$ responses on depolarization because they express voltage-gated $\mathrm{Ca}^{2+}$ channels together with other voltage-gated channels $[6,24]$. Therefore, we tested the depolarization-dependent $\mathrm{Ca}^{2+}$ responses of $\mathrm{ACh}-$ responding cells.

Among 83 ACh-responding cells, 75 cells (90\%) responded with increased $\left[\mathrm{Ca}^{2+}\right]_{\text {in }}$ due to the depolarization induced by the application of the $50 \mathrm{mM} \mathrm{K}^{+}$bathing solution to their basolateral membranes (Fig. 3). Among $9250 \mathrm{mM}$ $\mathrm{K}^{+}$-responding cells, 75 cells ( $82 \%$ ) responded to ACh. These results suggest that most of the ACh-responding cells expressed voltage-gated $\mathrm{Ca}^{2+}$ channels.
Fig. 1 ACh-induced $\mathrm{Ca}^{2+}$ responses of TBCs. a $\mathrm{Ca}^{2+}$ imaging of a single taste bud (upper row) and their subtracted images (lower row, i.e., 3-2: the subtraction of frame 2 from frame 3). ACh $(1 \mu \mathrm{M})$ was applied as shown in frame 3. b Overlay of $\mathrm{Ca}^{2+}$ imaging of ACh-responding TBCs (3-2) in a and a differential interference contrast image of the taste bud. c Respective AChinduced responses of the numbered TBCs in $\mathbf{b}$. The numerals in trace no. 1 are identical to the frame numbers in a

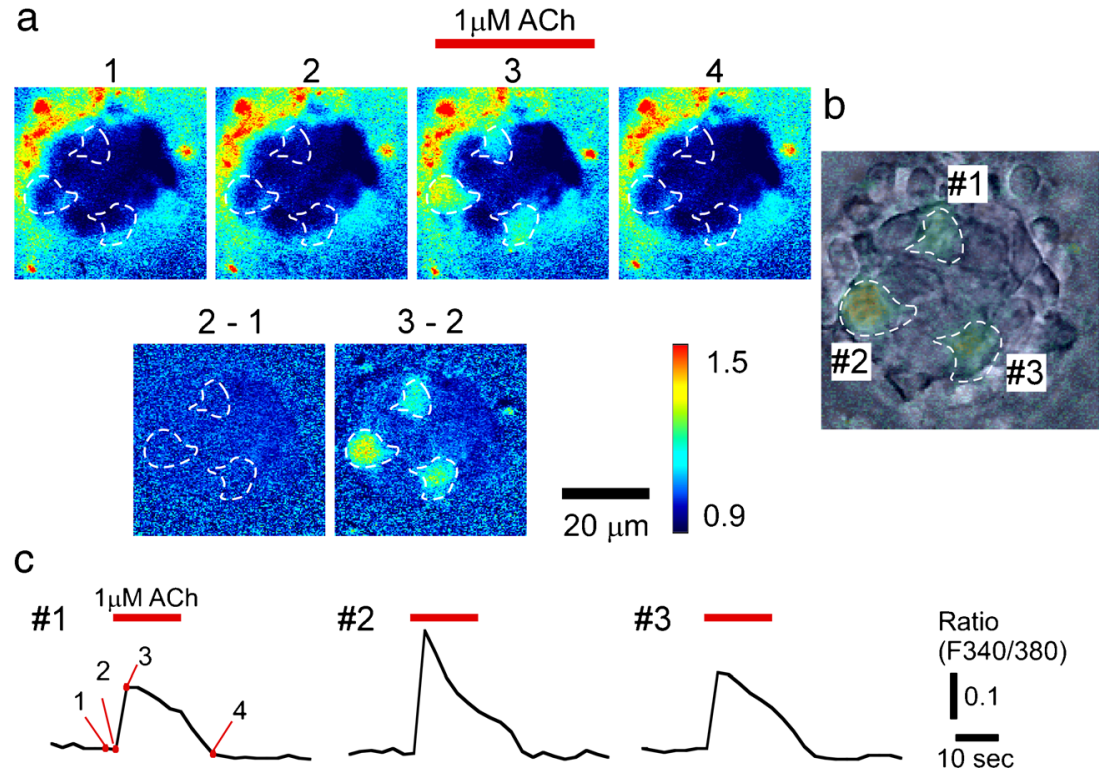




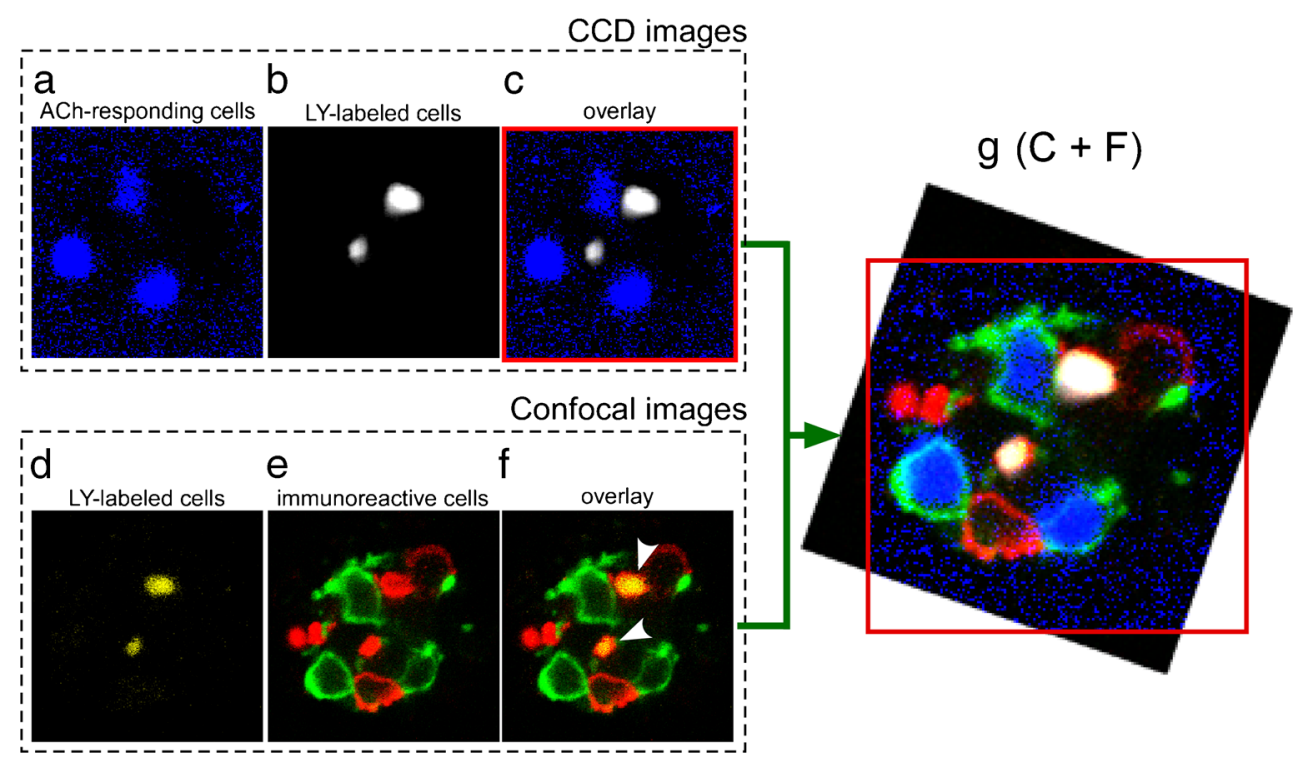

Fig. 2 Positional relationships among ACh-responding cells, LY-labeled cells, and immunohistochemical cell types in the same taste bud. a Monochrome image of ACh-responding cells shown in Fig. 1a (3-2). b Image of LY-labeled cells. c Overlay with a red outline on the frame. d Confocal image of LY-labeled cells in the same taste bud shown in a-c. e Confocal image of immunoreactive cells. f Overlay. $\mathbf{g}$ Overlay of $\mathbf{c}$ and $\mathbf{f}$, where $\mathbf{f}$ is rotated to superimpose LY-labeled cells. As shown by the red

\section{Transduction mechanism of the ACh response}

The ACh-induced $\mathrm{Ca}^{2+}$ responses occurred in the nominally $\mathrm{Ca}^{2+}$-free bathing solution (Fig. 4a). The application of $1 \mu \mathrm{M}$ U73122, a phospholipase C (PLC) inhibitor, to the basolateral membrane side significantly decreased the $\mathrm{Ca}^{2+}$ response to $0.31 \pm 0.22$ times the magnitude of the control response $(n=5$, $p<0.008$, one-tailed paired $t$ test; Fig. $4 \mathrm{~b}$ ). Washing the taste bud with the control bathing solution failed to recover the magnitude of the response. The application of $1 \mu \mathrm{M}$ U73343, a negative control, had no effects $(0.90 \pm 0.21$, $n=5, p>0.14$ one-tailed paired $t$ test; Fig. $4 \mathrm{c}$ ).

These results show that in response to $\mathrm{ACh}, \mathrm{M} 3$ caused the release of $\mathrm{Ca}^{2+}$ from intracellular stores via the activation of a PLC. Thus, we found that SNAP-25-immunoreactive cells expressed M3 and exhibited $\mathrm{Ca}^{2+}$ responses via a PLC cascade. This cascade never contains PLC $\beta 2$ and $\mathrm{IP}_{3} \mathrm{R} 3$, because

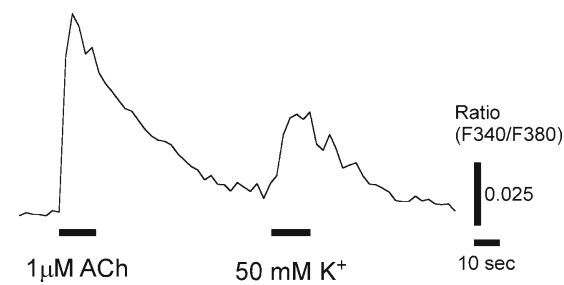

Fig. $3 \mathrm{Ca}^{2+}$ response of ACh-responding cells to $50-\mathrm{mM} \mathrm{K}^{+}$-induced depolarization. Representative trace of both $\mathrm{ACh}$ - and high $\mathrm{K}^{+}$-induced responses obtained from the same TBCs. Bars under the trace show the duration of $\mathrm{ACh}$ or $\mathrm{KCl}$ solution application as indicated. outline, the four corners of $\mathbf{c}$ have been eliminated. ACh-responding cells, blue; LY-labeled cells, white in images $\mathbf{b}, \mathbf{c}$, and $\mathbf{g}$, and yellow in images $\mathbf{d}$, f, and $\mathbf{g}$; PLC $\beta 2$-immunoreactivity, red; SNAP-25-immunoreactivity, green. Arrowheads in $\mathbf{f}$ show the overlap of PLC $\beta 2$ and LY. It should be noted that images $\mathbf{d}-\mathbf{f}$ were acquired after fixation for immunohistostaining (color figure online)

type III cells are non-immunoreactive to them. We, therefore, searched for molecules involved in this cascade with RT-PCR by extracting mRNAs from whole taste buds, not single cells.

Our RT-PCR analyses detected mRNAs for PLC $\beta 3$ and $\mathrm{IP}_{3} \mathrm{R} 1$ in addition to $\mathrm{PLC} \beta 2$ and $\mathrm{IP}_{3} \mathrm{R} 3$ in the fungiform taste buds (Fig. 5). The same results were obtained in duplicate experiments.

a

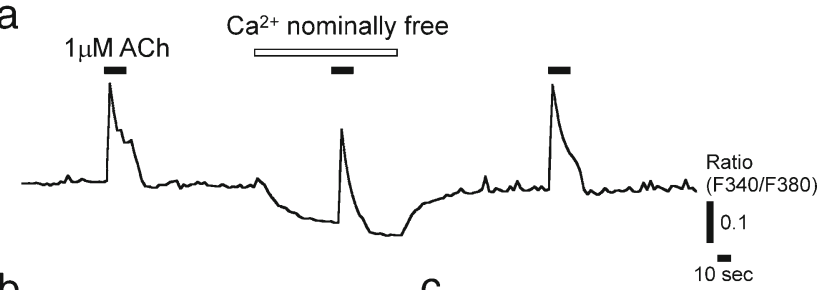

b

C

$1 \mu \mathrm{M} \mathrm{ACh}$

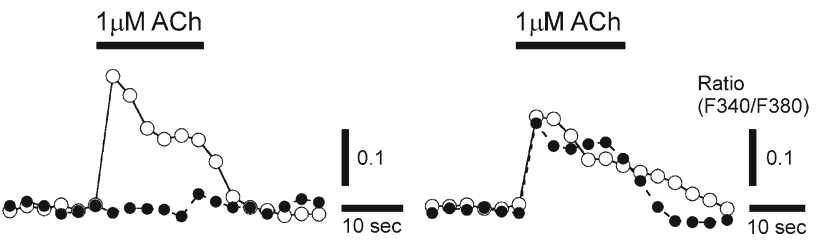

Fig. 4 Effects of $\left[\mathrm{Ca}^{2+}\right]_{\text {out }}$ and PLC inhibitors on the ACh-induced $\mathrm{Ca}^{2+}$ responses of single TBCs. a Representative $\mathrm{Ca}^{2+}$ responses in different $\left[\mathrm{Ca}^{2+}\right]_{\text {out }}$. Closed bars, the duration of ACh application; open bar, duration of the application of nominally $\mathrm{Ca}^{2+}$-free solution. b Representative $\mathrm{Ca}^{2+}$ responses in the absence (open circles) and presence (closed circles) of $1 \mu \mathrm{M}$ U73122. $\mathbf{c}$ Responses examined with $1 \mu \mathrm{M}$ U73343, a negative control for U73122. Overlaid traces were obtained from the same single TBCs 


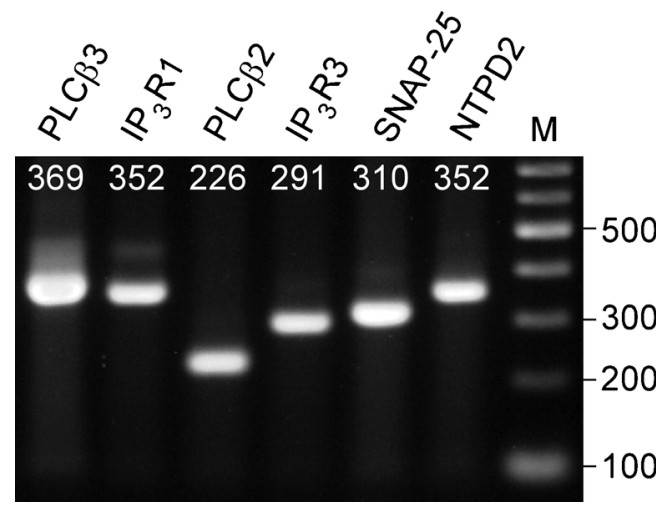

Fig. 5 Expression of PLC $\beta 3$ and $\mathrm{IP}_{3} \mathrm{R} 1 \mathrm{mRNAs}$ in fungiform taste buds. Electrophoresis image of the PCR products. Isolated taste buds from mouse fungiform papilla expressed mRNAs for $P L C \beta 3$ and $I P_{3} R 1$, in addition to those for PLC $32, I P_{3} R 3, S N A P-25$, and NTPD2. Numerals on each line indicate the expected product size. $M$ molecular size marker

\section{Discussion}

The results of the present study showed that all of the AChresponding cells were immunoreactive to SNAP-25 and that $90 \%$ of them increased $\left[\mathrm{Ca}^{2+}\right]_{\text {in }}$ in response to $50-\mathrm{mM} \mathrm{K}^{+}$induced depolarization. The type III cells were immunoreactive to SNAP-25 [35], and they expressed voltage-gated $\mathrm{Ca}^{2+}$ channels $[6,24]$. Therefore, we conclude that all AChresponding cells are type III cells.

Ten of 44 SNAP-25 immunoreactive cells $(\sim 23 \%$, $0.7 \pm 1.0$ cells per taste bud) were insensitive to ACh. In addition, 8/85 ACh-responding cells $(\sim 9 \%)$ were insensitive to depolarization, and $17 / 9550 \mathrm{mM} \mathrm{K}{ }^{+}$-responding cells $(\sim 18 \%)$ were insensitive to ACh. These results show that the type III cells differed in terms of the expression of M3 and voltage-gated channels. Type III cells may comprise multiple subtypes.

Our results demonstrated that $\mathrm{Ca}^{2+}$ responses occurred in the nominally $\mathrm{Ca}^{2+}$-free bathing solution and that a PLC inhibitor, U73122, decreased the magnitude of the $\mathrm{Ca}^{2+}$ response. These results suggest that in response to $\mathrm{ACh}$ by type III cells, M3 activates an $\mathrm{IP}_{3}$ cascade that releases $\mathrm{Ca}^{2+}$ from intracellular stores. No type III cells were immunoreactive to $\mathrm{G} \alpha$ gustducin, $\mathrm{PLC} \beta 2$, and $\mathrm{IP}_{3} \mathrm{R} 3[3,6,30]$. However, our RT-PCR study detected mRNAs for PLC $\beta 3$ and $\mathrm{IP}_{3} \mathrm{R} 1$ in fungiform taste buds, thereby suggesting that type III cells functionally express these proteins. Their expression was also detected immunohistochemically in mouse $\mathrm{IP}_{3} \mathrm{R} 3-\mathrm{GFP}-$ negative cells [9]. Furthermore, members of the $\mathrm{G} \alpha \mathrm{q} / 11$ family, such as $\mathrm{G} \alpha 14$ and $\mathrm{G} \alpha 15$, were detected in mRNA and protein forms [22, 31, 33]. Therefore, it is likely that type III cells or at least a subtype of them possess an $\mathrm{IP}_{3}$ cascade that differs from that of type II cells and that they release $\mathrm{Ca}^{2+}$ from intracellular $\mathrm{Ca}^{2+}$ stores in response to $\mathrm{ACh}$.

The role of M3 in the taste response of type III cells remains unknown. Type III cells are known to sense acidic substances $[14,17,36]$ and are considered to mediate the taste response of type II cells to taste nerve fibers [10, 13, 15]. It has been shown that M3-deficient mice are hypophagic and lean, which is probably due to the ingestion of lesser food than their wild-type littermates [34]. In addition, in islets, M3 has been shown to mediate the potentiation of glucose-induced insulin release via $\mathrm{IP}_{3}$ cascades $[1,7]$. Therefore, it is possible that $\mathrm{M} 3$ contributes to the appropriate maintenance of the appetite by potentiating the release of neurotransmitters from type III cells.

The source of ACh release in taste buds is not fully understood, although $\mathrm{ACh}$ is a neurotransmitter released from the parasympathetic nervous system and is responsible for stimulating "rest-and-digest." Immunohistochemical studies have shown that type II cells or trigeminal nerve fibers within the taste buds contain a vesicular ACh transporter $[8,28]$. Also, the release of ACh from type II cells has been detected physiologically [5]. The mechanism of ACh release from type II cells remains to be investigated.

The results of the present study showed that M3 occurs only on type III cells but not on type II cells or nonimmunoreactive cells. These results do not agree with those of a previous study, which demonstrated the presence of M3 on mouse type II cells [5]. This discrepancy may be due to differences in the materials and methods employed. In the present study, we used fungiform taste buds in situ and measured $\left[\mathrm{Ca}^{2+}\right]_{\text {in }}$ with Fura-2 in the presence of $2 \mathrm{mM} \mathrm{Ca}^{2+}$. By contrast, the previous study used sliced circumvallate taste buds with calcium green dextran or calcium orange in the presence of $8 \mathrm{mM} \mathrm{Ca}^{2+}$. The $\mathrm{Kd}$ values of the $\mathrm{Ca}^{2+}$-sensing dyes employed were similar; hence, the discrepancy may be due to differences between the fungiform and the circumvallate taste buds. Furthermore, $8 \mathrm{mM} \mathrm{Ca}^{2+}$ was used, which is much higher than physiological $\mathrm{Ca}^{2+}$ concentrations, which may have resulted in the discrepancy.

In a previous paper [8], we discussed the possibility that M3 occurs on type II cells. However, the present results clearly show the selective expression of M3 on type III cells.

Acknowledgments This research was partially supported by Mr. Motoaki Miyoshi, the president of the Miyoshi rice store, and by JSPS KAKENHI Grant Number 15K07053.

Compliance with ethical standards All of the experiments were performed in accordance with the Guiding Principles for the Care and Use of Animals in the Field of Physiological Sciences approved by the Council of the Physiological Society of Japan, and they were permitted by the Animal Institutional Review Board of Kyushu Institute of Technology in accordance with the guidelines of the US National Institutes of Health.

Open Access This article is distributed under the terms of the Creative Commons Attribution 4.0 International License (http:// creativecommons.org/licenses/by/4.0/), which permits unrestricted use, distribution, and reproduction in any medium, provided you give appropriate credit to the original author(s) and the source, provide a link to the Creative Commons license, and indicate if changes were made. 


\section{References}

1. Boschero AC, Szpak-Glasman M, Carneiro EM, Bordin S, Paul I, Rojas E, Atwater I (1995) Oxotremorine-m potentiation of glucoseinduced insulin release from rat islets involves M3 muscarinic receptors. Am J Phys 268:E336-E342

2. Chandrashekar J, Mueller KL, Hoon MA, Adler E, Feng L, Guo W, Zuker CS, Ryba NJ (2000) T2Rs function as bitter taste receptors. Cell 100:703-711

3. Clapp TR, Yang R, Stoick CL, Kinnamon SC, Kinnamon JC (2004) Morphologic characterization of rat taste receptor cells that express components of the phospholipase $\mathrm{C}$ signaling pathway. J Comp Neurol 468:311-321

4. Dando R, Roper SD (2009) Cell-to-cell communication in intact taste buds through ATP signalling from pannexin 1 gap junction hemichannels. J Physiol 587:5899-5906. doi:10.1113 /jphysiol.2009.180083

5. Dando R, Roper SD (2012) Acetylcholine is released from taste cells, enhancing taste signalling. J Physiol 590:3009-3017. doi:10.1113/jphysiol.2012.232009

6. DeFazio RA, Dvoryanchikov G, Maruyama Y, Kim JW, Pereira E, Roper SD, Chaudhari N (2006) Separate populations of receptor cells and presynaptic cells in mouse taste buds. J Neurosci Off J Soc Neurosci 26:3971-3980

7. Duttaroy A, Zimliki CL, Gautam D, Cui Y, Mears D, Wess J (2004) Muscarinic stimulation of pancreatic insulin and glucagon release is abolished in $\mathrm{m} 3$ muscarinic acetylcholine receptor-deficient mice. Diabetes 53:1714-1720

8. Eguchi K, Ohtubo Y, Yoshii K (2008) Functional expression of M3, a muscarinic acetylcholine receptor subtype, in taste bud cells of mouse fungiform papillae. Chem Senses 33:47-55

9. Hacker K, Laskowski A, Feng L, Restrepo D, Medler K (2008) Evidence for two populations of bitter responsive taste cells in mice. J Neurophysiol 99:1503-1514

10. Hayato R, Ohtubo Y, Yoshii K (2007) Functional expression of ionotropic purinergic receptors on mouse taste bud cells. J Physiol 584:473-488

11. Herness S, Zhao FL, Kaya N, Lu SG, Shen T, Sun XD (2002) Adrenergic signalling between rat taste receptor cells. J Physiol 543:601-614

12. Herness S, Zhao FL, Lu SG, Kaya N, Shen T (2002) Expression and physiological actions of cholecystokinin in rat taste receptor cells. J Neurosci Off J Soc Neurosci 22:10018-10029

13. Huang YA, Dando R, Roper SD (2009) Autocrine and paracrine roles for ATP and serotonin in mouse taste buds. J Neurosci Off J Soc Neurosci 29:13909-13918. doi:10.1523/JNEUROSCI.235109.2009

14. Huang YA, Maruyama Y, Stimac R, Roper SD (2008) Presynaptic (type III) cells in mouse taste buds sense sour (acid) taste. J Physiol 586:2903-2912

15. Huang YJ, Maruyama Y, Dvoryanchikov G, Pereira E, Chaudhari N, Roper SD (2007) The role of pannexin 1 hemichannels in ATP release and cell-cell communication in mouse taste buds. Proc Natl Acad Sci U S A 104:6436-6441

16. Kataoka S, Toyono T, Seta Y, Ogura T, Toyoshima K (2004) Expression of $\mathrm{P} 2 \mathrm{Y} 1$ receptors in rat taste buds. Histochem Cell Biol 121:419-426

17. Kataoka S, Yang R, Ishimaru Y, Matsunami H, Sevigny J, Kinnamon JC, Finger TE (2008) The candidate sour taste receptor, PKD2L1, is expressed by type III taste cells in the mouse. Chem Senses 33:243-254

18. Kaya N, Shen T, SG L, Zhao FL, Herness S (2004) A paracrine signaling role for serotonin in rat taste buds: expression and localization of serotonin receptor subtypes. Am J Physiol Regul Integr Comp Physiol 286:R649-R658
19. Kim YV, Bobkov YV, Kolesnikov SS (2000) Adenosine triphosphate mobilizes cytosolic calcium and modulates ionic currents in mouse taste receptor cells. Neurosci Lett 290:165-168

20. Kimura K, Ohtubo Y, Tateno K, Takeuchi K, Kumazawa T, Yoshii K (2014) Cell-type-dependent action potentials and voltage-gated currents in mouse fungiform taste buds. Eur J Neurosci 39:24-34. doi:10.1111/ejn.12388

21. Kinnamon SC, Vandenbeuch A (2009) Receptors and transduction of umami taste stimuli. Ann N Y Acad Sci 1170:55-59

22. Kusakabe Y, Yamaguchi E, Tanemura K, Kameyama K, Chiba N, Arai S, Emori Y, Abe K (1998) Identification of two alpha-subunit species of GTP-binding proteins, Galpha15 and Galphaq, expressed in rat taste buds. Biochim Biophys Acta 1403:265-272

23. Kusakabe Y, Yasuoka A, Asano-Miyoshi M, Iwabuchi K, Matsumoto I, Arai S, Emori Y, Abe K (2000) Comprehensive study on $\mathrm{G}$ protein alpha-subunits in taste bud cells, with special reference to the occurrence of Galphai2 as a major Galpha species. Chem Senses 25:525-531

24. Medler KF, Margolskee RF, Kinnamon SC (2003) Electrophysiological characterization of voltage-gated currents in defined taste cell types of mice. J Neurosci Off J Soc Neurosci 23: 2608-2617

25. Nelson G, Chandrashekar J, Hoon MA, Feng L, Zhao G, Ryba NJ, Zuker CS (2002) An amino-acid taste receptor. Nature 416:199202. doi:10.1038/nature726

26. Nelson G, Hoon MA, Chandrashekar J, Zhang Y, Ryba NJ, Zuker CS (2001) Mammalian sweet taste receptors. Cell 106:381-390

27. Ogura $\mathrm{T}$ (2002) Acetylcholine increases intracellular $\mathrm{Ca} 2+$ in taste cells via activation of muscarinic receptors. J Neurophysiol 87 : 2643-2649

28. Ogura T, Margolskee RF, Tallini YN, Shui B, Kotlikoff MI, Lin W (2007) Immuno-localization of vesicular acetylcholine transporter in mouse taste cells and adjacent nerve fibers: indication of acetylcholine release. Cell Tissue Res 330:17-28

29. Ohtubo Y, Iwamoto M, Yoshii K (2012) Subtype-dependent postnatal development of taste receptor cells in mouse fungiform taste buds. Eur J Neurosci 35:1661-1671. doi:10.1111/j.14609568.2012.08068.x

30. Ohtubo Y, Yoshii K (2011) Quantitative analysis of taste bud cell numbers in fungiform and soft palate taste buds of mice. Brain Res 1367:13-21. doi:10.1016/j.brainres.2010.10.060

31. Shindo Y, Miura H, Carninci P, Kawai J, Hayashizaki Y, Ninomiya Y, Hino A, Kanda T, Kusakabe Y (2008) G alpha14 is a candidate mediator of sweet/umami signal transduction in the posterior region of the mouse tongue. Biochem Biophys Res Commun 376:504 508. doi:10.1016/j.bbrc.2008.09.035

32. Takeuchi K, Seto Y, Ohtubo Y, Yoshii K (2011) Dye-permeable, voltage-gated channel on mouse fungiform taste bud cells. Brain Res 1373:17-24. doi:10.1016/j.brainres.2010.12.019

33. Tizzano M, Dvoryanchikov G, Barrows JK, Kim S, Chaudhari N, Finger TE (2008) Expression of Galpha14 in sweet-transducing taste cells of the posterior tongue. BMC Neurosci 9:110. doi:10.1186/1471-2202-9-110

34. Yamada M, Miyakawa T, Duttaroy A, Yamanaka A, Moriguchi T, Makita R, Ogawa M, Chou CJ, Xia B, Crawley JN, Felder CC, Deng CX, Wess J (2001) Mice lacking the M3 muscarinic acetylcholine receptor are hypophagic and lean. Nature 410:207-212. doi: $10.1038 / 35065604$

35. Yang R, Crowley HH, Rock ME, Kinnamon JC (2000) Taste cells with synapses in rat circumvallate papillae display SNAP-25-like immunoreactivity. J Comp Neurol 424:205-215

36. Yoshida R, Miyauchi A, Yasuo T, Jyotaki M, Murata Y, Yasumatsu K, Shigemura N, Yanagawa Y, Obata K, Ueno H, Margolskee RF, Ninomiya Y (2009) Discrimination of taste qualities among mouse fungiform taste bud cells. J Physiol 587:4425-4439. doi:10.1113 /jphysiol.2009.175075 